\title{
References
}

Vogt, P. (1965) Zur Geologie von Südwest-Hinks Land (Ostgrönland $\left.71^{\circ} 30^{\prime} \mathrm{N}\right)$. Meddr Gr $\phi$ nland, Bd. 154, Nr. 5.

Wenk, E. (1956) Alpines und ostgrönlandisch-kaledonisches Kristallin, ein tektonisch-petrogenetischer Vergleich. Verh. naturf. Ges. Base1, Bd. 67, 75-102.

\section{FIELD MAPPING IN UPPER PALAEOZOIC AND MESOZOIC SEDIMENTS OF SCORESBY LAND AND JAMESON LAND}

T. Birkelund and K. Perch-Nielsen

Work on mapping southern Scoresby Land and Jameson Land started in 1968 as part of the five years project of mapping the whole Scoresby Sund region. Three field parties spent the six-week season mapping in the northern part of the area.

One of the main problems was to correlate the existing - but not yet published - maps of the eastern part of the area (Trümpy and Grasmück, in press; Callomon, in press) with a map of the western part of the area (prepared by M.Aellen) ${ }^{+}$. Special attention was given to the comparison of the lithology of the different formations in the western and eastern parts of the Jameson Land basin.

Upper Palaeozoic sediments are exposed at the western and eastern borders of the basin, while the central part is covered by Triassic and Jurassic sediments. These were the major subject of study this year.

+) These maps and manuscripts of descriptions were placed at our disposal by the generosity of the cited authors. 


\begin{tabular}{|c|c|c|c|}
\hline & \multicolumn{2}{|c|}{$\begin{array}{l}\text { Lithostratigraphical units in Scoresby Land } \\
\text { and Northern Jameson Land }\end{array}$} & $\begin{array}{l}\text { Approximate } \\
\text { thickness (m) }\end{array}$ \\
\hline $\begin{array}{l}\text { Upper } \\
\text { Jurassic }\end{array}$ & \multicolumn{2}{|l|}{ Koch Fjeld Formation } & $300+$ \\
\hline \multirow{3}{*}{$\begin{array}{l}\text { Middle } \\
\text { Jurassic }\end{array}$} & \multirow{3}{*}{ Vardekl $\phi$ ft Formation } & $\begin{array}{l}\text { Upper Vardekl } \phi \mathrm{ft} \\
\text { Member }\end{array}$ & \multirow{3}{*}{$\begin{array}{l}170 \\
280-500+ \\
60-100\end{array}$} \\
\hline & & $\begin{array}{l}\text { "The Yellow } \\
\text { Series" }\end{array}$ & \\
\hline & & $\begin{array}{l}\text { Lower Vardeki } \phi \mathrm{ft} \\
\text { Member }\end{array}$ & \\
\hline Liassic & Neills Klint Formation & & $360-440$ \\
\hline $\begin{array}{l}\text { Rhaetic- } \\
\text { Liassic }\end{array}$ & Kap Stewart Formation & & $200-400$ \\
\hline \multirow{2}{*}{ Triassic } & Kap Biot Formation & $\begin{array}{l}\text { Ørsted Dal Member } \\
\text { Fleming Fjord Member } \\
\text { Kap Seaforth Member }\end{array}$ & $\begin{array}{l}80-140 \\
10-240 \\
90-140\end{array}$ \\
\hline & $\begin{array}{l}\text { Mt. Nordenskjøld } \\
\text { Formation }\end{array}$ & $\begin{array}{l}\text { Solfaldsdal Member } \\
\text { Paradigma Member }\end{array}$ & $\begin{array}{l}60-250 \\
450+\end{array}$ \\
\hline $\begin{array}{l}\text { Lower } \\
\text { Scythian }\end{array}$ & $\begin{array}{l}\text { Wordie Creek } \\
\text { Formation }\end{array}$ & & $\begin{array}{l}250 \\
\text { (Rødstaken) } \\
360\end{array}$ \\
\hline
\end{tabular}

Lithostratigraphical classifications of the Triassic and the Jurassic sediments in this area have been dealt with by Koch (1929a, 1929b), Rosenkrantz (1929, 1934), Noe-Nygaard (1934), Stauber (1942), Trümpy (1961) and Callomon (1959, 1961). The following classification was used preliminarily in the field mapping and is in accordance with Callomon (1961) and Trümpy (1961).

The Wordie Creek Formation is only exposed in the eastern and western parts of the basin. It consists of dark brown and green, silty shales 
and sandstones with few poorly preserved ophiceratid ammonites. In the western part of the area the so-called $R \phi d$ staken member, mentioned by M. Aellen in Trümpy (1961), overlies the Wordie Creek Formation (in a restricted sense). It consists of a coarse basal conglomerate and reddishgrey sandstones with flute casts, ripple marks, cross-bedding, slump structures and parting lineation. Anodontophora and Claraia occur sporadically. The sandstones grade into the arkoses of the overlying Paradigma beds. The member can be compared to the uppermost sandstones in the Wordie Creek Formation in the Nathorst Fjord area.

The Paradigma Member consists of arkoses and conglomerates with angular red feldspar components, quartz and boulders of metamorphic, igneous and volcanic rocks. The arkoses are usually cross-bedded and often poorly cemented.

The Solfalds Dal Member and the lower part of the Kap Seaforth Member consist of gypsum-bearing shales, silts and sandstones. A marine calcareous horizon described by Trümpy and Grasmück ("the Myalina horizon") could be observed in most of the area.

The upper part of the Kap Seaforth Member is built up by alternating dolomitic and calcareous layers containing algal structures and pseudo-oolitic horizons. Sandy and shaly intercalations with mud cracks, ripple marks and burrows are common. Occasionally Anodontophora occurs.

The Fleming Fjord Member consists of red mudstones intercalated with subordinate sandy and calcareous beds. The bedding planes very often show mud cracks, ripple marks, and traces.

The lower part of the $\varnothing$ rsted Dal Member consists of alternating sandstones and mudstones. In the younger part the sandstones are dominant. They are often cross-bedded and contain poorly preserved plants remains. In the uppermost part dolomitic horizons occur. A bone-bed marks the contact with the overlying Kap Stewart Formation in the eastern part of the area. In the western part some erosion took place at this level.

The Kap Stewart Formation is built up of sandstones and black shales with poor plant fossils and occasionally thin coal layers. The sandstones are cross-bedded and poorly sorted.

The Neills Klint Formation consists of rather well sorted brownish, micaceous sandstones, intercalated with more poorly sorted sandstone 
horizons and black shales. Flaser structures, ripple marks and trace fossils are common. Marine Toarcian fossils occur.

The Vardeklфft Formation consists of a lower shale and silt member with calcareous concretions(Lower Vardekl $\phi \mathrm{ft}$ Member), a sandy and silty member ("The Yellow Series") and an upper shale and silt member (Upper Vardekl $\phi \mathrm{ft}$ Member). The thickness of the Yellow Series increases to the north. In the southern part of the area a rich fauna occurs in the Yellow Series and in the Upper Vardekl $\phi \mathrm{ft}$ Member (described by Spath (1932) and Callomon (1959, 1961)). Callomon distinguishes nine ammonite zones. The uppermost contains forms typical of the north-west European Sigaloceras calloviense zone, whereas the other zones contain pure boreal ammonite faunas. New finds in the boreal Arcticoceras kochi zone of ammonites similar to forms from the European Oxycerites aspidoides zone seem to confirm Callomon's correlation of this zone with the European section.

The youngest Mesozoic beds in the area mapped belong to the so-called Koch Fjeld Formation. It consists of coarse massive sandstones of doubtful, but probably Upper Jurassic age.

Tertiary dolerite intrusions can be observed as dykes and sills. throughout the area, the sills predominantly within the Kap Stewart Formation, where they can reach up to $100 \mathrm{~m}$.

Faults of mainly Tertiary age generally strike N-S and caused folding of incompetent layers in the Wordie Creek Formation near Werners Bjerge, a Tertiary intrusive massif in the north-western part of the area.

Among Quaternary deposits worth noting are "plateau gravels" on the tops of some mountains in the southern part of the area. At Fleming Fjord, Nathorst Fjord, and Carlsberg Fjord postglacial terrasses up to $70 \mathrm{~m}$ have been observed.

\section{References}

Callomon, J.H. (1959) The ammonite zones of the Middle Jurassic Beds of East Greenland. Geol. Mag., Vol. 96, 505-513.

Callomon, J.H. (1961) The Jurassic System in East Greenland. In Raasch, G. H. (edit.) Geology of the Arctic, Vol. 1, 258-268.

Koch, Lauge (1929a) The geology of East Greenland. Meddr Grфnland, Bd. 73, Afd. 2, Nr. 1 . 
Koch, Lauge (1929b) Stratigraphy of Greenland. Meddr Gr $\phi$ nland, Bd. 73, Afd. 2, Nr. 2 .

Noe-Nygaard, A. (1934) Stratigraphical outlines of the area round Fleming Inlet (East Greenland). Meddr Grфnland, Bd. 103, Nr. 1.

Rosenkrantz, A. (1929) Preliminary account of the geology of the Scoresby Sound district. In Koch, Lauge. The geology of East Greenland. Meddr Grфnland, Afd. 2, Nr. 1, 135-154.

Rosenkrantz, A. (1934) The Lower Jurassic rocks of East Greenland; Part I. Meddr Grфnland, Bd. 110, Nr. 1.

Spath, L. F. (1932) The invertebrate faunas of the Bathonian-Collovian deposits of Jameson Land (East Greenland). Meddr Grønland, $\mathrm{Bd} .87, \mathrm{Nr} .7$.

Stauber, H. (1942) Die Triasablagerungen von Ostgrönland. Meddr Grфnland, Bd. $132, \mathrm{Nr} .1$.

Trümpy, R. (1961) Triassic of East Greenland. In Raasch, G. H. (edit.) Geology of the Arctic, Vol. 1, 248-254.

\section{AN INVESTIGATION OF THE TERTIARY BASALTS IN SCORESBY SUND}

\section{W. Stuart Watt}

Work on mapping the Tertiary basalts in the western part of the Scoresby Sund area started in the summer of 19.68 as part of the five year project of mapping the whole region. One field party spent six weeks making detailed observations and extensive collections from a number of sections in the basalts.

$1800 \mathrm{~m}$ of the upper part of the basalt succession were examined in an area extending from Kap Stevenson in the east to a nunatak south of the inner part of Gaasefjord in the west and to the southern part of Milne Land 